\title{
TAX REVENUE AND ECONOMIC GROWTH NEXUS: EMPIRICAL EVIDENCE FROM THE NIGERIAN ECONOMY
}

\author{
Agunbiade, Olabode', \\ Idebi, Alesanmi Abraham ${ }^{2 \mathrm{i}}$ \\ ${ }^{1}$ Department of Economics, \\ University of Abuja, \\ Abuja, Nigeria \\ ${ }^{2}$ Department of Economics, \\ Nile University of Nigeria, \\ Abuja, Nigeria
}

\begin{abstract}
:
This paper examined the relationship between tax revenue and economic growth in Nigeria over 1981-2019 period, with special focus on Companies Income Tax, Value Added Tax and Petroleum Profits Tax. The data were sourced from the National Bureau of Statistics (NBS) and the Federal Inland Revenue Service (FIRS). The study employed the Vector Error Correction Model (VECM) to establish the nature and strength of the relationship between taxation and economic growth. The Johansen test of cointegration reveals that there is at least one cointegrating equation in the long-run between the variables. Granger causality test found a causal relationship among Real GDP and the different tax components. The impulse response functions and the variance decomposition analysis uphold the findings that the impact of the shock in the indirect tax (VAT) and direct tax (CIT and PPT) on GDP growth does not die out over the specified period under consideration. Variance decomposition analysis found that the effect of the shock to the direct tax (CIT and PPT) on GDP growth tends to be low, whereas the effect of the shock to the indirect tax (VAT) on GDP growth tends to be significant to increase over the period. Therefore, this study recommended that in order to expand tax revenue, there should be a broad base tax strategy, focusing on all key areas of the tax system with measurable outcomes. Emphasis should be on simplification of the tax system and ease of implementation with priority given to quick wins and low hanging fruits, while more challenging aspects should be deferred until positive results are being recorded. The regulatory authorities charged with the responsibility of collecting tax should further be strengthened to enforce compliance by taxpayers, among other recommendations.
\end{abstract}

JEL: C1, H20, H21

i Correspondence: email bodeagun@gmail.com, sanmiidebi@yahoo.co.uk 
Keywords: companies income tax, petroleum profits tax, value added tax, GDP and VECM.

\section{Introduction}

The issue of economic growth has since historical times occupied a central place in economic discourse. Economic growth is the basis of increased prosperity (Shaver \& Flyer, 2000). It has become generally accepted to represent increase in the production of goods and services or progress or development. Various economic growth theories have thus evolved over time, depending on the period and on the dynamics of the economy. Also, improvements in mathematical and statistical tools have had significant impact in formulating new concepts. The pertinent question that can be asked in this regard are based on the rationale and the main determinants of economic growth.

Many researchers, economists and Nobel Prize winners have tried to answer these questions. Economic growth can be considered a main factor in the well-being and prosperity of billions of people. Industrialisation and advances in technology have left a gap between developed countries and the developing ones. For example, in the 21st century, the GDP/capita of many poorer countries is lower than the GDP per capita of Europe and other advanced countries of the world in the 19th century. Economic growth reached a pinnacle of the $20^{\text {th }}$ Century that ensured the development of the Western World and improved many people's living standards. In respect of the economic growth concept, Denison (1962) affirmed that economic growth is the increase of real GDP or GDP per capita, an increase of national product that is measured in constant prices.

Economic growth is influenced by indirect factors such as institutions (financial institutions, private administrations etc.), the size of the aggregate demand, savings and investment rates, the efficiency of the financial system, budgetary and fiscal policies, migration of labour and capital and the efficiency of the government, to mention only a few. There are also differences between economic and non-economic determinants. "Proximate" or economic determinants refers to factors like capital accumulation, technological progress, labour and "ultimate" or non-economic sources refers to factors like government efficiency, institutions, political and administrative systems, cultural and social factors, geography and demography (Acemoglu, Johnson, Robinson, \& Yared, 2009).

The three main roles of a government, as attributed to Asoni \& Sanandaji (2009) are: (i) protection of the society from violence and invasion by other independent societies' military forces; (ii) protection of every member of the society from the injustice or oppression of other members through administration of justice and; (iii) erecting and maintaining public institutions and those public works, which cannot be expected that any individual, or small number of individuals, should erect or maintain. The level of execution of all these three roles depends on the state of the society and level of development. These views are similarly expressed by Gwartney, Lawson, \& Block (1996), who state the two main purposes of government as protection of individual's property 
rights and provision of public goods and services. In terms of economic theory, government exists to intervene where there is market failure, due to markets failing to maximise gains from efficient trade in achieving the most effective outcome for society (Adu \& Alagidede, 2012).

There are several ways that government intervenes in an economy; the most popular of which constitutes taxation as a means of sourcing financing for the provision of public goods and services. Tax in this regard represents the monetary value realised from taxation, while taxation itself represents all the processes through which the tax is collected. A good tax system has the traits of equity in terms of progressivity thereof and efficiency in terms of collection thereof. The role of government of any country is to provide public goods and services which cannot be provided by private individuals due mainly to the free riders' challenge. In carrying out these functions, government levies taxes on relevant taxable persons. In this regard, taxes have a role to play in the economic growth of any country of which Nigeria is not an exception.

Taxation is a very important tool for managing the economy. It represents the crucial component in contemporary business and their relevance is manifested through stability and predictability (Kalaš, B., Pjanić, Milenković, \& Andrašić, 2016). Tax is a compulsory levy imposed on a subject or upon his property by the government to provide security, social amenities and create conditions for the economic well-being of the society (Ebimobowei \& Ebiringa, 2012). Tax is a major player in every society of the world (Azubike, 2009). Keying into this line of argument, Nzotta (2007) further argued that taxes constitute key sources of revenue to the Federation Account in Nigeria that is appropriated by the federal, state and local governments. Ebimobowei \& Ebiringa (2012) also stated that taxes are imposed to regulate the production of certain goods and services, protection of infant industries, control of businesses, curbing of inflation, reduction of income inequalities, etc. Similarly, Tosun \& Abizadeh (2005), submitted that taxes are used as proxies for fiscal policy (negatively or positively). Abomaye-Nimenibo, et al., (2017) are of the view that tax is a compulsory contribution made by animate and inanimate beings to government, being a higher authority, either directly or indirectly to fund its various activities and any refusal is met with appropriate sanctions.

In view of the above, the following specific research questions are to be addressed in this study:

1) Is there a relationship between taxes and economic growth in Nigeria?

2) Is this relationship based on the type of taxes analysed?

The specific research objectives of this study are to examine the nexus between taxes and economic growth in Nigeria, while the general objectives are as follows:

1) To determine the relationship between taxes and economic growth in Nigeria.

2) To assess the impact of different types of tax on economic growth in Nigeria.

Based on the research objectives above, the appropriate hypotheses, which are in Null form, for this study, are as follows:

$\mathbf{H}_{01}$ : There is a significant positive relationship between taxation and economic growth in Nigeria. 
$\mathrm{H}_{02}$ : The relationship between taxes and economic growth in Nigeria is influenced by tax types.

The above study is justified in the sense that various studies have been carried out on the relationship between taxes and economic growth in Nigeria or at best the impact of taxes on economic growth in Nigeria and several other developing countries, with differing outcomes. However, there have not been many recent studies that took into account the current tax collection trends where tax revenues have been growing from few millions in the 1980s to the current trillions of Nigerian Naira annually, accompanied by decaying infrastructural facilities and stagflationary trend in the economy.

In terms of sequence, this paper is organised as follows: Section one is the introduction, which provides an overview of economic development and taxation system in Nigeria. Section two contains the review of several relevant literatures on the subject. This is closely followed by Section three which represents the methodology employed in testing this relationship. Section four is devoted to the empirical results and analysis, while the final Section five contains the conclusion and recommendations in line with the results obtained.

\section{Review of Literature}

\subsection{Conceptual Literature}

\subsubsection{Concept of Taxation}

The word 'tax' is derived from the Latin word 'taxo', that is to estimate the value or compute the value (Lewis, Short, Andrews, \& Freund, 1975). 'Tax' is defined as a regular and compulsory payment made by citizens to the government to pay for governmental services consumed by the citizens. These types of payments to the state are as old as the "State" itself. For centuries, the public domain was the major source of public revenue. Azubike (2009) equally defined tax as a compulsory levy imposed on a subject or his/her property by the government to provide social amenities and create conditions for the economic prosperity of the society. Likewise, Chigbu \& Njoku (2015) emphasize that tax is a major source of revenue for every economy and it's usually an instrument used in reducing the gap between the rich and the poor.

Taxation is also looked at by Afuberoh \& Okoye (2014) as a compulsory levy by the government through its agencies on the income, consumption and capital of its subjects. These levies are made on personal income, such as salaries, business profits, interests, dividends, discounts and royalties as well as company's profits, petroleum profits, capital gains. Tax can further be defined as a compulsory levy enforced by tax authorities on income, expenditure, wealth or people, for which nothing is received by the taxpayers directly or specifically in return (Shang, 2016). Among the many ways that governments can generate revenues, tax revenue is recognised as the most important financial source for governmental public expenditures (Frecknall-Hughes, 2014).

Taxation, apart from providing rapid economic growth, can also be used to encourage or discourage certain activities considered to be socially, friendly and 
unfriendly. To Udabah (2002), tax is evil necessary to meet the cost of those services a society wishes its government to provide. He sees it as an obligatory transfer from taxpayers to the public authority. According to Ogbonna \& Appah (2016), tax is "a major source of government revenue all over the world". Azubuike (2009), noted that government uses tax proceeds to render their traditional function such as the provision of public goods, maintenance of law and order, defense against external aggression, regulation of trade and business to ensure social economic maintenance. Musgrave, Musgrave, \& Bird (1989) observed that the economic effects of tax include micro effects on the distribution of income and efficiency of resource use as well as macro effect on the level of capacity output, employment, prices and growth. Ebimobowei (2010) stated that a tax is a compulsory payment imposed on income, profit, wealth, estate, property, goods and services of individuals and corporate bodies by the government for the sustenance of the government and for which there is no guaranteed direct benefit. Taxes represent potent instrument of fiscal policy used by government to manage the economic development of the state.

Anyanwu (1993) stated that tax is more or less compulsory, non-returnable contribution of money used occasionally for goods and services and flows from private individuals, institutions or groups to the government. It may be levied upon wealth or income of a person or body corporate or in form of surcharge on prices. To Okpe (1998), taxation is regarded as a compulsory charge imposed by the public authority (Federal, State and Local Government) for the general purposes of Government. It is also defined as the act of laying a tax or imposing taxes on the subjects of a state by government or on the members of a corporation or company by the proper Authority. Once levied, every taxable person must pay tax.

\subsubsection{Tax Capacity and Tax Efforts}

Tax revenue which is always seen as the key revenue form in the government's fiscal budgetary revenue system, has drawn the attention of many scholars for a very long time. In terms of the measurement of the tax performance, two questions are very germane: what is the potential of tax revenue, and how are these tax revenue potentials utilised to generate tax revenue by government that is responsible for the utilisation of the tax revenue to provide public goods and services. Hence, two important terms are discussed: the tax capacity, which measures the potential tax revenues; and the tax effort, which indicates the efficiency of tax collection (Le, Moreno-Dodson, \& Bayraktar, 2012). Tax capacity means: to what extent can government raise its tax revenue to achieve a perfect balance with economic growth? Thus, tax capacity is the hypothetical ability of tax authority units to raise revenue for the purpose of public finance, within the existing available tax base (Shang, 2016). Tax effort on the other hand states that: given the hypothetical ability to collect tax revenue, how do tax collection authority units direct their effort to collect taxes? In other words, tax effort refers to the extent to which an area or governmental body generates tax revenue from its tax capacity (Shang, 2016). 


\subsection{Theoretical Framework}

According to Ayuba (2014) a tax revenue theory may be derived on the assumption that there need not be any relationship between tax paid and benefits received from state activities. We shall accordingly look at some of such theories as discussed below:

\subsubsection{Socio-Political Theory}

This theory of tax revenue states that social and political objectives should be the major factors in selecting taxes. The theory advocates that a tax system should not be designed to serve individuals, but should be used to cure the ills of society as a whole.

\subsubsection{Benefit Received Theory}

This theory is based on the assumption that there is basically an exchange relationship between taxpayers and the state because the state provides certain goods and services to the members of the society. Therefore, members of the society should contribute to the cost of these supplies in proportion to the benefits received (Ayuba, 2014).

\subsubsection{Faculty Theory}

According to Ayuba (2014), this theory states that one should be taxed according to the ability to pay. It is simply an attempt to maximise an explicit value judgment about the distributive effects of taxes. Ayuba (2014) argues that a citizen is to pay tax just because he can, and his relative share in the total tax burden is to be determined by his relative paying capacity.

\subsubsection{Expediency Theory}

This theory asserts that every tax proposal must pass the test of practicality. It must be the only consideration weighted by the authorities in choosing a tax proposal. Economic and social objectives of the state and the effects of a tax system should be treated as irrelevant (Ayuba, 2014). Ofishe (2015) explained that the expediency theory is based on a link between tax liability and state activities. It assumes that the state should charge the members of the society for the services provided to it. This reasoning justifies imposition of taxes for financing state activities by inferences, which provides a basis for apportioning the tax burden between members of the society. This proposition has a reality embedded in it, since it is useless to have a tax which cannot be levied and collected efficiently.

\subsection{Empirical Review}

Many studies have examined not only the impact of taxation on economic growth, but also the nexus between taxation and economic growth, given that the issue of taxation and economic growth are at the heart of macroeconomic policies. This part of the paper focuses on the key properties of the selected empirical studies that investigated the relationship between economic growth and taxes. This empirical review will not be limited only to Nigerian studies, but will also focus on diverse results in terms of 
causality, irrespective of geographical area. Examination of the causality between economic growth and tax is a topic of numerous debates, notwithstanding the disagreement on a unified theoretical approach.

Some of the studies that established a negative relationship between taxation and economic growth include: Badri, Dizaji, \& Allahyari (2013), Zellner \& Ngoie (2015), Atems (2015), Ojede \& Yamarik (2012), Dackehag \& Hansson (2012), Szarowska (2010) and Stoilova (2017). Dowrick (1992) carried out a study for a sample of Organisation for Economic Co-operation and Development (OECD) countries between 1960 and 1985 and established a strong negative effect of personal income taxation, but no impact of corporate taxes. Easterly \& Rebelo (1993) found some measures of the tax distortion (such as an imputed measure of marginal tax rates) to be correlated negatively with output growth, although other measures of the tax distortion were insignificant in the growth equations.

Badri, et al., (2013) analysed the effects of tax and Gross Domestic Product (GDP) on employment in Iran during the years 1976-2007 based on the Auto-Regressive Distribution Lag model (ARDL). The results obtained from the estimation of long-term and short-term patterns reveal that tax has a negative and significant effect on employment and GDP has a positive and significant effect on employment. Marimuthu, Arokiasamy, \& Ismail (2009); Zellner \& Ngoie (2015) also conducted studies on the impact of tax on economic growth, using the Marshallian macroeconomic model in the United States between the period 1987 to 2008. The studies concluded that corporate taxes are harmful to economic growth. Dladla \& Khobai (2018) explored the effects of taxation in Zimbabwe over the period 1980 to 2012 using granger causality test and vector error correction model to test the relationship. The results show that taxes affect the allocation of resource and distort the growth of the economy.

Stoilova (2017) further carried out a research on exploring the relationship between tax structure and economic growth, focusing on the 28 European Union countries from 1996 to 2013. The author used Barro's endogenous model and found that total revenue has an effect on the economy. The researcher found that personal income tax has positive impact on economic growth, while corporate taxes have a negative impact on growth. Kneller, Bleaney, \& Gemmell (1999) used a panel of 22 OECD countries for the period 1970-1995 and identified a depressing effect of so called 'distortionary taxes', which include taxes on income and property. These findings are further confirmed by the analysis of Gemmell, Kneller, \& Sanz (2006), which provided new evidence on the long-run impact of distortionary taxes on growth in OECD countries, by updating and extending datasets to cover 1970-2004.

It is however argued that even though most of the studies and theories underline negative relationships between economic growth and taxation, some other empirical research found positive relationships. Some of these studies include: Babatunde, Ibukun, \& Oyeyemi (2017) and Dladla \& Khobai, (2018). Tax implemented alone takes a considerably long period to impact economic growth. Babatunde, et al., (2017) conducted a study to examine the relationship between taxation and economic growth in Africa 
from the periods 2004 to 2013. The pre-estimation test carried out was descriptive statistics and unit root tests, which showed that the variables GDP and tax were normal and stationary. The findings for this study indicated that tax revenue is positively related to GDP and promotes economic growth in Africa. Dladla \& Khobai (2018) studied the relationship between tax policies and economic growth in 21 member nations of the Organisation for Economic Cooperation and Development (OECD) over the period 1980 to 1999 using the random effect model (REM). The result reveals the evidence of relationship between taxes and economic growth, with positive and significant results on personal income tax and corporate tax.

In the final analysis, some studies established no relationship between taxation and economic growth. Shaver \& Flyer (2000) examined the effect of taxes on economic growth in the United Kingdom from the period 1950 to 1998, using exogenous and endogenous growth models. The findings reveal that the relationship between tax and economic growth is very weak and in practice, taxation does not affect the rate of growth. A similar study was embarked upon by Gemmell, et al., (2006) examined the link between taxes and economic growth in 21 OECD countries over the period 1970 to 2004 using the Error Correction Model (ECM. The study showed corporate and personal taxes to be insignificant. Ojong, Anthony, \& Arikpo, (2016) undertook the study of investigating the impact of tax revenue on economic growth in Nigeria over the period 1986 to 2010 using the ordinary least square method. The findings reveal the insignificant relationship between tax revenue received from companies and economic growth. In summary, the empirical studies considered above showed the results are mixed; from negative to positive and to no relationships.

\section{Methodology}

\subsection{Research Design}

The main objective of this study is to establish whether there is a connection existing between taxes and economic growth in Nigeria; thus, leading to an explanatory study. As earlier discussed, the nature of the study will be quantitative, which tries to investigate the hypothesis of the impact of the independent variables (tax types) on the dependent variable (GDP). In this regard, a linear regression model will be employed for purposes of establishing this relationship.

\subsection{Research Data and Sources}

The study utilised secondary data for the variables identified in the model. In an attempt to establish the impact of major reforms in Nigeria over an extended period, for which taxation and growth data are available, the data will cover the period 1981 to 2019, to assess whether these reforms and the various business cycles also influenced the relationship between taxes and economic growth. In order to obtain sufficient data, the data was obtained on yearly basis, as per published GDP data for the years under consideration. Data used in this study were sourced as follows: growth data, being GDP 
was obtained from the National Bureau of Statistics (NBS), while tax revenue data were obtained from reports and other publications of the Federal Inland Revenue Service (FIRS), Nigeria.

\subsection{Model Specification}

Flowing from growth theory in macro-economics, GDP can be derived by using either of two different methods:

A. The expenditure approach, which measures GDP as the sum of consumption expenditure, investment, government expenditure on goods and services, and net exports. That is:

$$
\mathrm{GDP}=\mathrm{C}+\mathrm{I}+\mathrm{G}+(\mathrm{X}-\mathrm{M})
$$

where:

$$
\begin{aligned}
& \text { GDP }(Y)=\text { Household consumption }(C)+\text { Investments }(I)+\text { Government } \\
& \text { expenditure }(G)+\text { Net imports }(X-M)
\end{aligned}
$$

or,

B. The income approach, where:

$$
\text { GDP }(\mathrm{Y})=\text { Household consumption }(\mathrm{C})+\text { Savings }(\mathrm{S})+\text { Taxes }(\mathrm{T})
$$

The aggregate expenditure approach is based on the total expenditure or spending on all final goods and services in an economy, whereas the aggregate income approach is calculated based on the factor income to factors of production, i.e. inputs to production.

The second model (income approach) will be the point of reference for this study as a result of the linear time series model to be derived for statistical analysis. This is because, unlike the expenditure approach, the income approach measures GDP by summing up the income that firms pay households for their labour and thereby incorporates taxes therein, which invariably links the income approach to the specific objective of the study, examining the link between GDP and Taxes.

The model for this study is specified as follows:

$$
\mathrm{GDPt}=\alpha \text { Taxes }+\kappa \mathrm{Xt}+\mu \mathrm{t} \text {. }
$$

This is then transformed to their logarithm form for ease of interpretation of the regression coefficients in the standardised form of percentage changes.

Thus, the model becomes:

$$
\text { GDPt }=\alpha_{0}+\alpha_{1} \ln (\text { Taxes }) \mathrm{t}+\alpha_{2} \ln (\text { cons }) \mathrm{t}+\alpha_{3} \ln (\text { sav }) \mathrm{t}+\mu
$$

Where: 
$\mathrm{t}$ is the time period, GDP $_{\mathrm{t}}$ is the Gross domestic product, Taxest represents Total Taxes, const is the total household consumption, and savt refers to savings as earlier indicated.

The relationship of taxes to economic growth will be analysed according to the three main tax types thus resulting in the model being further derived as follows:

$$
\mathrm{GDP}_{\mathrm{t}}=\beta_{0}+\beta_{1} \ln (\mathrm{CIT})_{\mathrm{t}}+\beta_{2} \ln (\mathrm{VAT})_{\mathrm{t}}+\beta_{3} \ln (\mathrm{PPT})_{\mathrm{t}}+\mu_{\mathrm{t}}
$$

Where:

CIT, PPT and VAT refer to Companies Income Tax, Petroleum Profit Tax, and Value Added Tax, respectively.

\subsection{Model Estimation}

In accordance with generally acceptable process of conducting time series analysis, this study first examined the unit root properties of the variables. The cointegration approach follows closely in order to determine the existence or otherwise of a long-run causal relationship as well as the resulting error correction model. Finally, the causal relationship between taxation including the various components and economic growth will be examined via Granger causality test.

\section{Data Presentation, Analysis and Interpretation of Results}

\subsection{Data Presentation}

Essentially, this paper covers four variables namely the Gross Domestic Product (GDP), Companies Income Tax (CIT), Petroleum Profit Tax (PPT) and Value Added Tax (VAT). The data were annual in nature and were sourced from the National Bureau of Statistics (NBS) and the Federal Inland Revenue Service (FIRS).

\subsection{Trend Analysis}

The graphical representation of the four series in their observation form are presented below: 
Figure 1: Graph of the GDP, PPT, CIT and VAT, 1981-2019

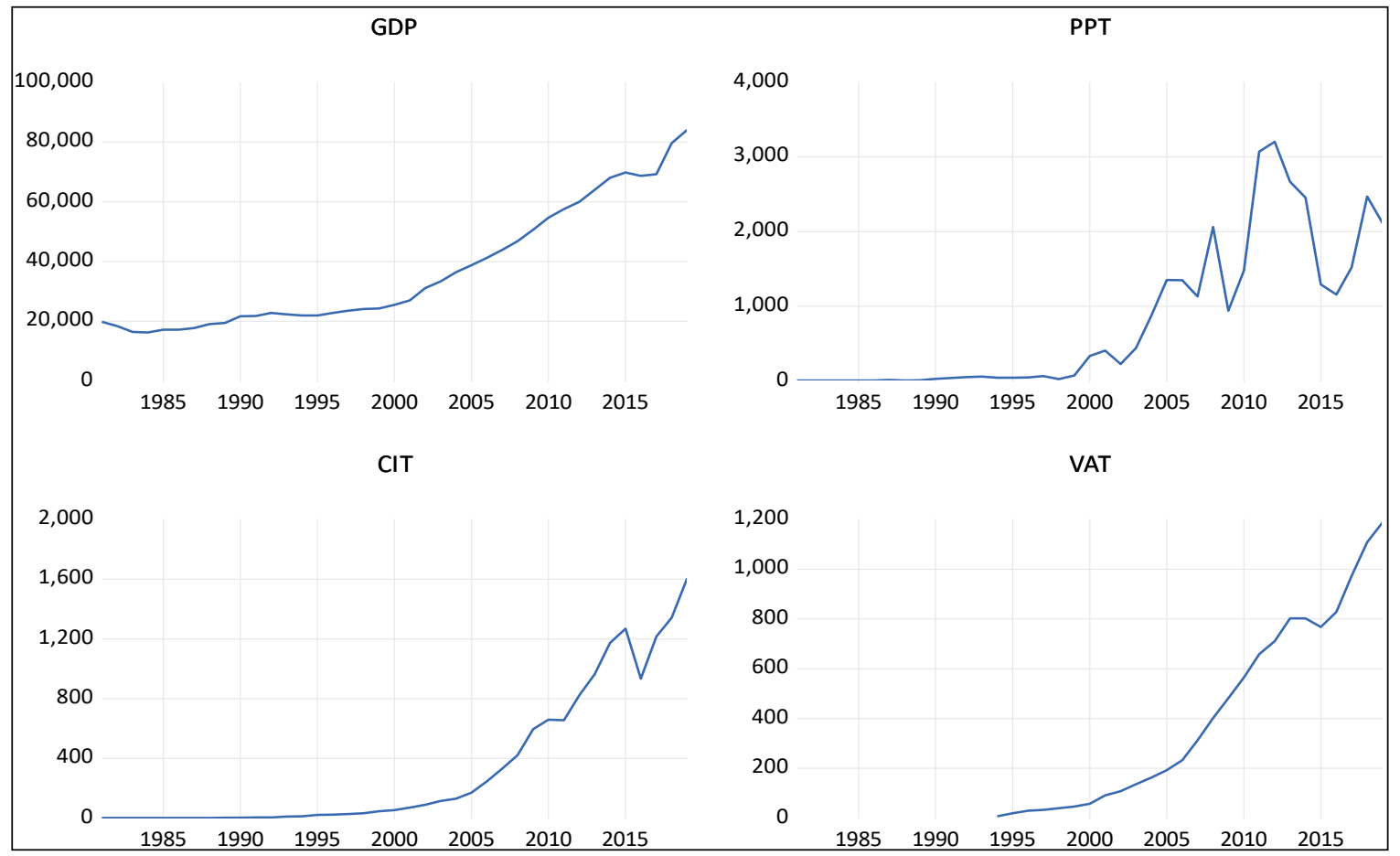

The above is graphical illustration showing that the movement, trends and fluctuations in the series.

\subsection{Descriptive Statistics of Data}

The descriptive statistics summarises the basic statistical features of the data under consideration including the mean, the minimum and maximum values, standard deviation, skewness, kurtosis and the Jarque-Bera test for the data. These descriptive statistics provide a historical background for the behaviour of our data.

Table 1: Descriptive Statistics

\begin{tabular}{|l|c|c|c|c|}
\hline & GDP & CIT & PPT & VAT \\
\hline Mean & 45690.33 & 500.8736 & 1185.755 & 413.8545 \\
\hline Median & 42482.04 & 289.55 & 1144.904 & 272.65 \\
\hline Maximum & 84064.36 & 1607.32 & 3201.32 & 1188.541 \\
\hline Minimum & 21881.56 & 12.2748 & 24.6 & 7.7 \\
\hline Std. Dev. & 19925.67 & 507.4835 & 1013.415 & 380.1085 \\
\hline Skewness & 0.340493 & 0.700773 & 0.491933 & 0.555107 \\
\hline Kurtosis & 1.794231 & 2.110274 & 2.077197 & 1.939712 \\
\hline Jarque-Bera & 2.077423 & 2.985603 & 1.971188 & 2.553182 \\
\hline Probability & 0.35391 & 0.224742 & 0.373217 & 0.278987 \\
\hline Sum & 1187949 & 13022.71 & 30829.62 & 10760.22 \\
\hline Sum Sq. Dev. & $9.93 \mathrm{E}+09$ & 6438487 & 25675228 & 3612063 \\
\hline Observations & $\mathbf{2 6}$ & $\mathbf{2 6}$ & $\mathbf{2 6}$ & $\mathbf{2 6}$ \\
\hline
\end{tabular}

Source: Authors' computation from Eviews 11, 2020. 
From Table 1, among the statistics shown, the Jarque-Bera test seems to be essential, as it is a test of normality distribution of the variables. Based on our results and using the Pvalues associated with the Jarque-Bera statistics, all the variables were normally distributed as the P-values were greater than 5\% probability level.

\subsection{Correlation matrix}

The correlation matrix is a table showing the correlation coefficients between the variables used in this paper. Each cell in the table shows the correlation between two variables. This correlation matrix is used as a way to summarise data, as input into a more advanced analysis, and as a diagnostic for advanced analyses.

Table 2: Correlation coefficients between the variables

\begin{tabular}{|l|c|c|c|c|}
\hline & GDP & CIT & PPT & VAT \\
\hline GDP & 1.0000 & & & \\
\hline CIT & 0.977947 & 1.0000 & & \\
\hline PPT & 0.808257 & 0.738064 & 1.0000 & \\
\hline VAT & 0.989058 & 0.984503 & 0.795356 & 1.0000 \\
\hline
\end{tabular}

Source: Authors' computation from Eviews 11, 2020.

From the Table 2, there is a strong and positive relationship between the GDP and CIT, GDP and PPT, GDP and VAT, CIT and PPT, CIT and VAT, PPT and VAT.

\subsection{Unit Root Test}

We used the Augmented Dickey Fuller (ADF) test to examine the stationarity of the variables so as to avoid the problem of spurious regression. The table below shows the unit root result.

Table 3: Stationarity Tests Result

\begin{tabular}{|l|c|c|c|c|c|}
\hline & \multicolumn{5}{|c|}{ Augmented Dickey Fuller (ADF)Unit Root Test } \\
\hline Variables & Critical Values & At level & Critical Value & At 1st Difference & Decision \\
\hline LGDP & -2.567984 & -3.20032 & $-4.458605^{* * *}$ & -4.226815 & $\mathrm{I}(1)$ \\
\hline LCIT & -0.097227 & -4.219126 & $-6.024527^{* * *}$ & -4.226815 & $\mathrm{I}(1)$ \\
\hline LVAT & $-3.279051^{*}$ & -3.238054 & & & $\mathrm{I}(0)$ \\
\hline LPPT & -2.337794 & -4.219126 & $-5.842179^{* * *}$ & -4.234972 & $\mathrm{I}(1)$ \\
\hline Note: ${ }^{* * *}$ Statistical significance at & 1\% level; ${ }^{* *}$ statistical significance at 5\%; ; Statistical significance at $10 \%$. \\
\hline
\end{tabular}

Source: Authors' computation using Eviews 11.

The outcome of the unit root tests using the Augmented Dickey Fuller (ADF) test presented in Table 3 reveals that all the variables were not stationary at level. While only VAT was stationary at level i.e. I (0), the GDP, LCIT and LPPT were stationary at first difference i.e. I (1), and were either significant at $1 \%, 5 \%$, or $10 \%$ as the case may be. Thus, the Vector Error Correction Model (VECM) will be employed to estimate the model. 


\subsection{Lag Length Selection Criteria}

Before the VECM procedure is examined, the optimum lag length selection criteria were carried out in order to determine the number of lag(s) to be included in the model prior to Johansson cointegration test. The optimum lag selection must be considered as this may result to the problem of misspecification and the problem of autocorrelation. The result is presented in the Table four below.

Table 4: Optimal Lag Length Selection Criteria

\begin{tabular}{|c|c|c|c|c|c|c|}
\hline Lag & LogL & LR & FPE & AIC & SC & HQ \\
\hline 0 & -2.315386 & NA & $1.99 \mathrm{e}-05$ & 0.526282 & 0.722625 & 0.578372 \\
\hline 1 & 90.76880 & 147.3833 & $3.31 \mathrm{e}-08$ & -5.897400 & $-4.915689^{*}$ & -5.636952 \\
\hline 2 & 112.3878 & $27.02372^{*}$ & $2.36 \mathrm{e}-08^{*}$ & $-6.365648^{*}$ & -4.598567 & $-5.896841^{*}$ \\
\hline
\end{tabular}

* indicates lag order selected by the criterion, LR: sequential modified LR test statistic (each test at $5 \%$ level), FPE: Final prediction error, AIC: Akaike information criterion, SC: Schwarz information criterion and HQ: Hannan-Quinn information criterion.

Source: Authors' Computation using E-views 11, 2020.

From Table 4, Akaike information criterion (AIC), Hannan-Quinn information criterion (HQ) and other criteria except for Schwarz information criterion (SC) indicated that two maximum lags are to be included in the model. Hence, our model will be the Akaike information criterion (AIC).

\subsection{Johansen Co-integration test}

Co-integration analysis helps to clarify the long-run relationships between integrated variables. Johansen's (1991) procedure is the maximum likelihood for the finite-order vector auto-regressions (VARS) and is easily calculated for such systems, so it will be used in this study. The result is presented below:

Table 5: Johansen Co-integration Test

\section{Unrestricted Cointegration Rank Test (Trace)}

\begin{tabular}{lcccc}
$\begin{array}{l}\text { Hypothesized } \\
\text { No. of CE(s) }\end{array}$ & Eigenvalue & $\begin{array}{c}\text { Trace } \\
\text { Statistic }\end{array}$ & $\begin{array}{c}\mathbf{0 . 0 5} \\
\text { Critical Value }\end{array}$ & Prob.** \\
\hline \hline & & & & \\
None* & 0.872341 & 77.41845 & 47.85613 & 0.0000 \\
At most 1 & 0.466314 & 28.01697 & 29.79707 & 0.0791 \\
At most 2 & 0.304432 & 12.94624 & 15.49471 & 0.1168 \\
At most 3* & 0.161718 & 4.233619 & 3.841465 & 0.0396
\end{tabular}

Trace test indicates 1 cointegrating eqn(s) at the 0.05 level

* denotes rejection of the hypothesis at the 0.05 level

**MacKinnon-Haug-Michelis (1999) p-values 
Unrestricted Cointegration Rank Test (Maximum Eigenvalue)

\begin{tabular}{lcccc}
\hline \hline $\begin{array}{l}\text { Hypothesized } \\
\text { No. of CE(s) }\end{array}$ & Eigenvalue & $\begin{array}{c}\text { Max-Eigen } \\
\text { Statistic }\end{array}$ & $\begin{array}{c}\mathbf{0 . 0 5} \\
\text { Critical Value }\end{array}$ & Prob.** \\
\hline \hline & & & & \\
None $^{*}$ & 0.872341 & 49.40148 & 27.58434 & 0.0000 \\
At most 1 & 0.466314 & 15.07073 & 21.13162 & 0.2840 \\
At most 2 & 0.304432 & 8.712622 & 14.26460 & 0.3109 \\
At most 3* & 0.161718 & 4.233619 & 3.841465 & 0.0396 \\
& & & & \\
\hline \hline
\end{tabular}

Max-eigenvalue test indicates 1 cointegrating eqn(s) at the 0.05 level

* denotes rejection of the hypothesis at the 0.05 level

**MacKinnon-Haug-Michelis (1999) p-values

Cointegration relationship between variables in the VAR model is generally tested with the Johansen and Juselius (1990) method. Johansen cointegration test on the Gross Domestic Product (GDP), Companies Income Tax (CIT), Petroleum Profit Tax (PPT) and Value Added Tax (VAT) in Table 5 above, shows that in both trace and maximum eigenvalue test, test results are to accept the null hypothesis, under the $5 \%$ level, and at least one cointegrating equation exist. This means there are stable and long-term equilibrium relationships among the variables. On the premise of the existence of cointegration relationships, VEC modeling can be further conducted.

\subsection{Vector Error Correction Model (VECM)}

It must be noted that error correction mechanism (ECM) is meant to tie the short-run dynamics of the cointegrating equations to their long-run static dispositions. In order to capture the short run fluctuation, the Vector Error Correction Method (VECM) was employed and the result is presented below.

Table 6: Vector Error Correction Estimates

Vector Error Correction Estimates

Date: 05/19/20 Time: 10:57

Sample (adjusted): 19972019

Included observations: 23 after adjustments

Standard errors in ( ) \& t-statistics in [ ]

Cointegrating Eq:

CointEq1 


\begin{tabular}{|c|c|c|c|c|}
\hline LGDP(-1) & 1.000000 & & & \\
\hline \multirow[t]{3}{*}{ LCIT(-1) } & 3.898816 & & & \\
\hline & $(0.61053)$ & & & \\
\hline & [ 6.38593] & & & \\
\hline \multirow[t]{3}{*}{ LVAT(-1) } & -5.028522 & & & \\
\hline & $(0.80672)$ & & & \\
\hline & {$[-6.23331]$} & & & \\
\hline \multirow[t]{3}{*}{ LPPT(-1) } & 0.281895 & & & \\
\hline & $(0.13796)$ & & & \\
\hline & [ 2.04331] & & & \\
\hline C & -6.387443 & & & \\
\hline Error Correction: & D(LGDP) & $\mathrm{D}(\mathrm{LCIT})$ & D(LVAT) & D(LPPT) \\
\hline \multirow[t]{3}{*}{ CointEq1 } & 0.019252 & -0.410289 & -0.134361 & -1.377177 \\
\hline & $(0.01595)$ & $(0.10517)$ & $(0.09588)$ & $(0.55449)$ \\
\hline & [ 1.20679] & {$[-3.90121]$} & {$[-1.40140]$} & [-2.48368] \\
\hline \multirow[t]{3}{*}{$\mathrm{D}(\operatorname{LGDP}(-1))$} & 0.587074 & -2.378845 & -1.615295 & -9.342455 \\
\hline & $(0.16057)$ & $(1.05854)$ & $(0.96501)$ & (5.58099) \\
\hline & [ 3.65622] & [-2.24729] & [-1.67387] & [-1.67398] \\
\hline \multirow[t]{3}{*}{$\mathrm{D}(\operatorname{LGDP}(-2))$} & 0.062509 & -1.862676 & -0.989124 & -9.307163 \\
\hline & $(0.13411)$ & $(0.88409)$ & $(0.80597)$ & $(4.66123)$ \\
\hline & [ 0.46612] & [-2.10689] & {$[-1.22725]$} & [-1.99672] \\
\hline \multirow[t]{3}{*}{$\mathrm{D}(\mathrm{LCIT}(-1))$} & 0.020406 & 0.713768 & 0.462212 & 3.419936 \\
\hline & $(0.04138)$ & $(0.27278)$ & $(0.24868)$ & (1.43819) \\
\hline & [ 0.49316] & [ 2.61665] & [ 1.85869$]$ & [ 2.37794] \\
\hline \multirow[t]{3}{*}{$\mathrm{D}(\mathrm{LCIT}(-2))$} & -0.194865 & 0.759733 & 0.536477 & 3.571428 \\
\hline & $(0.04437)$ & $(0.29250)$ & $(0.26665)$ & (1.54215) \\
\hline & [-4.39197] & [ 2.59740] & [ 2.01190] & [ 2.31588] \\
\hline \multirow[t]{3}{*}{ D(LVAT(-1)) } & 0.364835 & -1.074240 & -0.415735 & -3.950684 \\
\hline & $(0.07838)$ & $(0.51669)$ & $(0.47103)$ & $(2.72415)$ \\
\hline & [ 4.65497] & {$[-2.07910]$} & {$[-0.88261]$} & {$[-1.45024]$} \\
\hline \multirow[t]{3}{*}{$\mathrm{D}(\operatorname{LVAT}(-2))$} & -0.047283 & -0.053210 & -0.115191 & -1.065505 \\
\hline & $(0.02503)$ & $(0.16501)$ & $(0.15043)$ & $(0.87001)$ \\
\hline & {$[-1.88900]$} & {$[-0.32246]$} & {$[-0.76573]$} & [-1.22471] \\
\hline \multirow[t]{3}{*}{ D(LPPT(-1)) } & 0.005541 & 0.053948 & 0.059606 & -0.001419 \\
\hline & $(0.00598)$ & $(0.03945)$ & $(0.03597)$ & $(0.20801)$ \\
\hline & [ 0.92592] & [ 1.36741$]$ & [ 1.65724$]$ & {$[-0.00682]$} \\
\hline \multirow[t]{2}{*}{ D(LPPT(-2)) } & -0.008401 & 0.073526 & 0.048448 & -0.410338 \\
\hline & $(0.00668)$ & $(0.04405)$ & $(0.04016)$ & $(0.23227)$ \\
\hline
\end{tabular}




\begin{tabular}{lcccc}
\hline & {$[-1.25723]$} & {$[1.66902]$} & {$[1.20635]$} & {$[-1.76667]$} \\
C & 0.002033 & 0.310929 & 0.190475 & 0.812691 \\
& $(0.01253)$ & $(0.08259)$ & $(0.07529)$ & $(0.43545)$ \\
& {$[0.16224]$} & {$[3.76466]$} & {$[2.52976]$} & {$[1.86632]$} \\
\hline \hline & & & \\
R-squared & & & & 0.506209 \\
Adj. R-squared & 0.890895 & 0.675110 & 0.459378 & 0.164353 \\
Sum sq. resids & 0.815361 & 0.450186 & 0.085101 & 3.936010 \\
S.E. equation & 0.003258 & 0.141595 & 0.117678 & 0.550245 \\
F-statistic & 0.015831 & 0.104364 & 0.095143 & 1.480769 \\
Log likelihood & 11.79460 & 3.001506 & 1.227376 & -12.33433 \\
Akaike AIC & 69.27890 & 25.90266 & 28.03038 & 1.942116 \\
Schwarz SC & -5.154687 & -1.382840 & -1.567859 & 2.435809 \\
Mean dependent & -4.660994 & -0.889147 & -1.074166 & 0.164974 \\
S.D. dependent & 0.056732 & 0.184456 & 0.160847 & 0.601929 \\
\hline \hline
\end{tabular}

Determinant resid covariance (dof adj.)

Determinant resid covariance

Log likelihood

Akaike information criterion

Schwarz criterion

Number of coefficients
3.56E-09

3.64E-10

119.4037

$-6.556846$

$-4.384596$

44

Source: Authors' computation from Eviews 11, 2020.

In econometric analysis, it is practically difficult to interpret the results of multivariate models. We estimate these model in order to be able to test for Causality and compute Variance Decompositions and Impulse Response Functions. As suggested by Salisu (2015), before we proceed to Causality Test, Variance Decomposition \& Impulse Response Functions, we have to verify that the estimates of the chosen multivariate model are reliable. This will require diagnostic checks such as the residual serial correlation.

\subsection{VEC Residual Serial Correlation LM Tests}

From Table 7, the null hypothesis is that the no serial correlation in the error terms versus its alternative hypothesis of serial dependence among error terms. The probability of the LM test in the result has the values 0.6304 and 0.2717 for the two-lag period which are greater than the $5 \%$ level of significance, hence the null hypothesis of no serial correlation is accepted and we conclude that the result of this analysis is reliable and free from serial correlation. 
Table 7: Serial Correlation LM Tests

\begin{tabular}{lcc} 
Lags & LM-Stat & Prob \\
\hline \hline & & \\
1 & & \\
2 & 13.57461 & 0.6304 \\
& 18.94134 & 0.2717
\end{tabular}

Probs from chi-square with $16 \mathrm{df}$.

Source: Authors' computation using E-views 11.

\subsection{Granger Causality Test}

Cointegration test indicates a long-term equilibrium relationship between the two variables, but, in terms of causal relationship, further testing is needed. If variable $A$ is helpful in predicting $B$, namely, the regression of B is based on past values of $B$ and past values of $A$ are added, this can greatly enhance the explanatory ability of the regression. Then, A can be called Granger cause of B; otherwise, it can be called non-Granger cause. $P$ value is less than the significant level of $5 \%$, which indicates the need to accept the null hypothesis, namely the existence of Granger cause.

Table 8: Granger Causality Test result

\begin{tabular}{|c|c|c|c|}
\hline Null Hypotheses (H0) & Chi-Square & Probability & Remarks \\
\hline GDP does not Granger Cause CIT & 43.32949 & 0.0000 & \multirow[b]{2}{*}{ Bidirectional Causality } \\
\hline CIT does not Granger Cause GDP & 7.729979 & 0.0210 & \\
\hline GDP does not Granger Cause VAT & 22.46468 & 0.0000 & \multirow[b]{2}{*}{ Unidirectional Causality } \\
\hline VAT does not Granger Cause GDP & 3.555171 & 0.1690 & \\
\hline GDP does not Granger Cause PPT & 2.753188 & 0.2524 & \multirow[b]{2}{*}{ Unidirectional Causality } \\
\hline PPT does not Granger Cause GDP & 5.552079 & 0.0623 & \\
\hline CIT does not Granger Cause VAT & 4.957274 & 0.0839 & \multirow[b]{2}{*}{ No Causality } \\
\hline VAT does not Granger Cause CIT & 4.463306 & 0.1074 & \\
\hline CIT does not Granger Cause PPT & 4.172303 & 0.1242 & \multirow[b]{2}{*}{ Unidirectional Causality } \\
\hline PPT does not Granger Cause CIT & 6.513895 & 0.0385 & \\
\hline VAT does not Granger Cause PPT & 3.780273 & 0.1511 & \multirow[b]{2}{*}{ No Causality } \\
\hline PPT does not Granger Cause VAT & 4.600519 & 0.1002 & \\
\hline
\end{tabular}

Source: Author's computation from Eviews 11, 2020.

As the results reveal in Table 8 above, the GDP and CIT Granger cause each other, that is a bidirectional granger causality exist between GDP and CIT. There are Unidirectional Causality between GDP and VAT, GDP and PPT, CIT and PPT, while there is no Granger causality between CIT and VAT, and VAT and PPT where there is no Granger causality.

\subsection{Impulse Responses}

In order to analyse the dynamic effects of the model responding to certain shocks as well as how the effects are among the four variables, further analysis is made through impulse 
response function and variance decomposition based on VECM, and the results for 10 periods are obtained.

As has been pointed out in the literature, individual coefficients from the errorcorrection model are hard to interpret in the case of vector-auto- regressive model. VAR models are difficult to interpret. One solution is to construct an impulse response function (IRF). The IRF traces the response of the endogenous variables to one-standard deviation shock to one of the disturbance terms in the system. This shock is transmitted to all of the endogenous variables through the dynamic structure of the VEC models (Lutkepohl, Saikkonen, \& Trenkler, 2001). Consequently, the dynamic properties of the model are analysed by examining the impulse response functions and the variance decompositions. The impulse response functions trace the dynamic responses to the effect of shock in one variable upon itself and on all other variables i.e. it is a tool that portrays the expected path over time of the variable to shocks in the innovations. These impulse response functions are plotted in Figure 2.

Figure 2: Plot of the Impulse Response Function

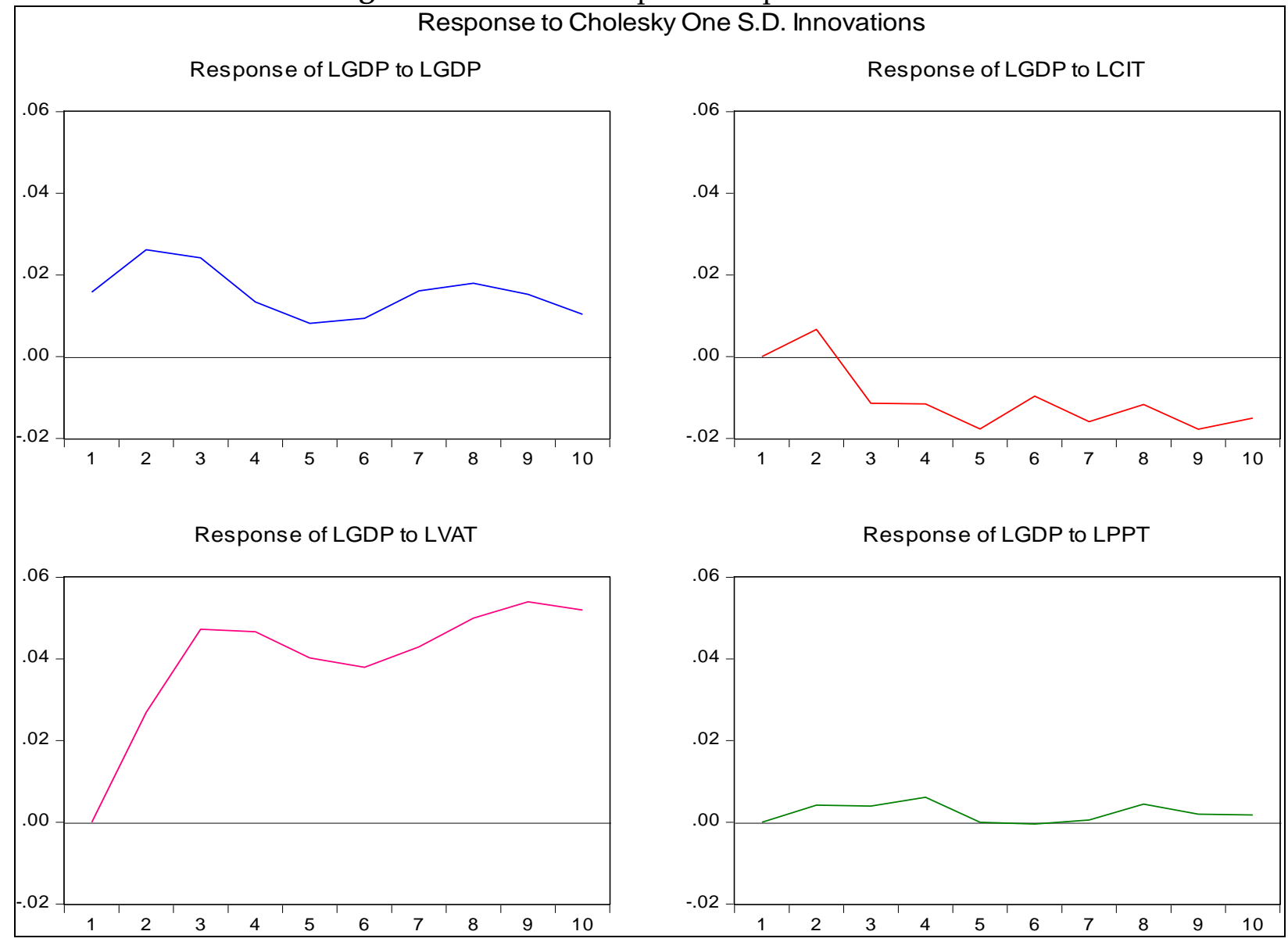

Source: Authors' own computation using Eviews 9, 2020.

As shown in Figure 2, a one standard deviation shock applied to gross domestic product produces positive effect on GDP throughout the period. What this seems to suggest is that there is an evidence in support of positive effect of GDP on its own shocks in Nigeria. 
A one standard deviation shock to CIT initially has positive perceptible effect on GDP in the short run; however, for a long period it has negative perceptible effect on GDP and causes output to decrease.

A one standard deviation shock to VAT has a huge and positive effect on GDP in the short run. The effect becomes noticeable in the long run. Lastly, A one standard deviation shock to PPT has positive but low effect on GDP. Between period 5 and 6.5, PPT has no effect on GDP. However, the effect becomes noticeable again as subsequent period shows that PPT's shock respond positively to GDP.

\subsection{Variance Decomposition of GDP}

Table 10: Variance Decomposition of GDP result

\begin{tabular}{lccccc}
\hline \hline Period & S.E. & LGDP & LCIT & LVAT & LPPT \\
\hline \hline & & & & & \\
1 & & & & & \\
2 & 0.015831 & 100.0000 & 0.000000 & 0.000000 & 0.000000 \\
3 & 0.041500 & 54.24893 & 2.595646 & 42.11682 & 1.038595 \\
4 & 0.068450 & 32.44496 & 3.729626 & 63.10676 & 0.718658 \\
5 & 0.084926 & 23.57699 & 4.272401 & 71.16471 & 0.985899 \\
6 & 0.095968 & 19.18386 & 6.739463 & 73.30460 & 0.772075 \\
7 & 0.104071 & 17.12684 & 6.591232 & 75.62401 & 0.657914 \\
8 & 0.114831 & 16.03272 & 7.335932 & 76.08869 & 0.542656 \\
9 & 0.127133 & 15.07442 & 6.835794 & 77.52453 & 0.565258 \\
10 & 0.140112 & 13.59507 & 7.229637 & 78.68931 & 0.485981 \\
& 0.150555 & 12.25211 & 7.258561 & 80.05384 & 0.435493 \\
\hline
\end{tabular}

Cholesky Ordering: LGDP LCIT LVAT LPP

Source: Authors' own computation using Eviews 9, 2020.

In the Table 10, the result for 10 periods were obtained. For the first period, we observe that a shock in GDP in the first period is responsible for $100 \%$ variation in the GDP (own shock), whereas there are no contributions of the shock in CIT, VAT and PPT for the variation of GDP during that period. In a shorter span of time, CIT affect GDP growth slightly more than the PPT. On the other hand, in the longer time span, VAT affect GDP growth significantly more than the CIT and PPT. The shock to VAT can better explain the variation in GDP growth with the increase in the length of the time period. In other words, VAT is responsible for over $60 \%$ variation in the GDP starting from period 3 and the subsequent periods.

\section{Conclusion and Recommendation}

This paper examined the relationship between taxation and economic growth in Nigeria over the 1981-2019 period, with special focus on Companies Income Tax, Value Added 
Tax, and Petroleum Profit Tax. The Johansen test of cointegration reveals that there is at least one cointegrating equation in the long-run between the variables. The study used a Vector Error Correction Model (VECM) to establish the nature and strength of relationship between taxation and economic growth. Granger causality test found a causal relationship among Real GDP and the different tax components. The impulse response functions and the variance decomposition analysis through Vector Error correction model (VECM) upholds the findings that the impact of the shock in the direct tax and indirect tax on GDP growth does not die out over the specified period under consideration. Variance decomposition analysis found that the effect of the shock to the direct tax (CIT and PPT) on GDP growth tends to be low, whereas the effect of the shock to the indirect tax (VAT) on GDP growth tends to be significant to increase over the period. On the CIT and PPT, the low level of tax compliance can be attributed to a number of factors including the cumbersome and inefficient tax administration system, ambiguities in the tax laws and lack of transparency regarding the utilisation of tax revenue for social services and visible development.

Therefore, it is recommended that in order to expand tax revenue, there should be a broad base tax strategy focusing on all key areas of the tax system with measurable outcomes. Emphasis should be on simplification of the tax system and ease of implementation with priority given to quick wins and low hanging fruits, while more challenging aspects should be deferred until positive results are being recorded. The regulatory authorities charged with the responsibility of collecting tax should further be strengthened to enforce compliance by taxpayers. Capacity building through both soft and technical training of personnel is key as no leading tax authority relies on the use of consultants for sustainable capacity building. In addition, tax authorities should undertake significant enlightenment and public awareness and exploit the advantages offered by technology and innovation including social media to enhance efficiency and effectiveness. Transparency is also critical; hence, full information about revenue and expenses with detailed breakdown should be made available to all stakeholders online.

\section{References}

Abomaye-Nimenibo, W. A. S., Abomaye-Nimenibo, C. T., Abomaye-Nimenibo, G. B. T., \& Abomaye-Nimenibo, R. A. (2017). The Lethargic Government Public Expenditure Torpedoing Economic Development in Nigeria from 1970-2014. Global Journal of Management and Business Research E-Marketing, 17(3), Version 1.0., 50-73.

Acemoglu, D., Johnson, S., Robinson, J. A., \& Yared, P. (2009). Reevaluating the Modernization Hypothesis. Journal of Monetary Economics, 56(8), 1043-1058.

Adu, G., \& Alagidede, P. (2012). Modern Macroeconomics: A Review of the post 2008/2009 crisis debate. African Review of Economics and Finance, 4(1), 73-88. 
Afuberoh, D., \& Okoye, E. (2014). The Impact of Taxation on Revenue Generation in Nigeria: A Study of the Federal Capital Territory and Selected States. International Journal of Public Administration and Management Research, 2(2), 22-47.

Anyanwu, J. C. (1993). Monetary Economics: Theory, Policy, and Institutions. Onitsha, Nigeria: Hybrid Publishers.

Asoni, A., \& Sanandaji, T. (2009). Taxation and the Quality and Quantity of Entrepreneurship, Research Institute of Industrial Economics, IFN Working Paper No. 813, 1-46.

Atems, B. (2015). Another Look at Tax Policy and State Economic Growth: The long-run and short-run of it. Economics Letters, 127, 64-67.

Ayuba, A. J. (2014). Impact of Non-oil Tax Revenue on Economic Growth: The Nigerian Perspective. International Journal of Finance and Accounting, 3(5), 303-309.

Azubike, J. (2009). Challenges of Tax Authorities, Tax Payers in The Management of Tax Reform Processes. Nigerian Accountant, 42(2), 36-42.

Azubuike, L. O. (2009). Privatization and Foreign investment in Nigeria. Boca Raton, Florida: Universal Publishers.

Babatunde, O. A., Ibukun, A. O., \& Oyeyemi, O. G. (2017). Taxation Revenue and Economic Growth in Africa. Journal of Accounting and Taxation, 9(2), 11-22.

Badri, A. K., Dizaji, M., \& Allahyari, S. (2013). An Analysis of the Effects of Taxes and GDP on Employment in Iran's Economy. European Online Journal of Natural and Social Sciences, 2(3 (s), 1546-1553.

Chigbu, E. E., \& Njoku, C. O. (2015). Taxation and the Nigerian Economy (1994-2012). Management Studies and Economic Systems (MSES),2(2), 111-128.

Dackehag, M., \& Hansson, A. (2012). Taxation of Income and Economic Growth: An Empirical Analysis of 25 Rich OECD countries. Journal of Economic Development, 21(1), 93-118.

Denison, E. F. (1962). The Sources of Economic Growth in the United States and the Alternatives Before Us. Supplementary Paper No. 13. New York: Committee for Economic Development.

Dladla, K., \& Khobai, H. (2018). The impact of Taxation on Economic Growth in South Africa. Munich Personal RePEc Archive (MPRA), 15 April.

Dowrick, S. (1992). Technological Catch up and Diverging incomes: Patterns of Economic Growth 1960-88. The Economic Journal, 102(412), 600-610.

Easterly, W., \& Rebelo, S. (1993). Fiscal Policy and Economic Growth. Journal of Monetary Economics, 32(3), 417-458.

Ebimobowei, A. (2010). The Relationship Between Fiscal Policy and Economic Growth in Nigeria (1991-2005). International Journal of Economic Development Research and Investment, 1(2), 37-46.

Ebimobowei, A., \& Ebiringa, O. (2012). Petroleum Profit Tax and Economic Growth in Nigeria. International Journal of Management Sciences and Business Research, 1(9), 1222. 
Frecknall-Hughes, J. (2014). The Theory, Principles and Management of Taxation: An Introduction. New York: Routledge.

Gemmell, N., Kneller, R., \& Sanz, I. (2006). Fiscal Policy Impacts on Growth in the OECD: Are they long-or short-term? University of Nottingham: Mimeo,

Gwartney, J. D., Lawson, R., \& Block, W. (1996). Economic Freedom of the World, 1975-1995. The Fraser Institute.

Johansen, S. (1991). Estimation and Hypothesis Testing of Cointegration Vectors in Gaussian Vector Autoregressive Models. Econometrica, 59, 1551-1580.

Johansen, S., \& Juselius, K. (1990). Maximum Likelihood Estimation and Inference on Cointegration-with Applications to the Demand for Money. Oxford Bulletin of Economics and Statistics, 52 (2), 169-210.

Kalaš, B., Pjanić, M., Milenković, N., \& Andrašić, J. (2016). Comparative Analysis Paying Taxes Indicator: Evidence from Western Balkans Countries and Turkey. International Journal of Management, Accounting and Economics, 3(4), 222-232.

Kalaš, B., Mirović, V., \& Milenković, N. (2018). The Relationship Between Taxes and Economic Growth: Evidence from Serbia and Croatia. The European Journal of Applied Economics, 15(2), 17-28.

Kneller, R., Bleaney, M. F., \& Gemmell, N. (1999). Fiscal Policy and Growth: Evidence from OECD Countries. Journal of Public Economics, 74(2), 171-190.

Le, T. M., Moreno-Dodson, B., \& Bayraktar, N. (2012). Tax Capacity and Tax Effort: Extended Cross-Country Analysis from 1994 to 2009. Washington DC: Investment Climate Department, The World Bank.

Lewis, C. T., Short, C., Andrews, E. A., \& Freund, W. (1975). A Latin Dictionary Founded on Andrews' Edition of Freund's Latin Dictionary Revised \& enlarged edition. Oxford: Clarendon Press.

Lutkepohl, H., Saikkonen, P., \& Trenkler, C. (2001). Maximum Eigenvalue Versus Trace Tests for the Cointegrating Rank of a VAR Process. The Econometrics Journal, 4(2), $287-310$

Marimuthu, M., Arokiasamy, L., \& Ismail, M. (2009). Human Capital Development and Its Impact on Firm Performance: Evidence from Developmental Economics. Journal of International Social Research, 2(8), 265-272.

Musgrave, R. A., Musgrave, P. B., \& Bird, R. M. (1989). Public Finance in Theory and Practice. New York: McGraw-Hill.

Nzotta, S. (2007). Tax Evasion Problems in Nigeria: A critique. The Nigerian Accountant, 12(1), 40-43.

Ofishe, O. W. (2015). The Impact of Value Added Tax on Economic Growth in Nigeria (1994 - 2012). Research Journal of Finance and Accounting, 6(23), 34-46.

Ogbonna, G., \& Appah, E. (2016). Effect of Tax Administration and Revenue on Economic Growth in Nigeria. Research Journal of Finance and Accounting, 7(13), 49-58.

Ojede, A., \& Yamarik, S. (2012). Tax Policy and State Economic Growth: The Long-Run and Short-Run of It. Economics Letters, 116(2), 161-165. 
Ojong, C. M., Anthony, O., \& Arikpo, O. F. (2016). The Impact of Tax Revenue on Economic Growth: Evidence from Nigeria. IOSR Journal of Economics and Finance, 7(1), 32-38.

Okpe, I. I. (1998). Personal Income Tax of Nigeria. Enugu: New Generation Books

Salisu, A. (2015). VAR, VEC and Toda-Yamamoto Models. Centre for Econometric \& Allied Research (CEAR), University of Ibadan.

Shang, J. (2016). An Empirical Study on China's Regional Tax Revenue Performance. Unpublished PhD Thesis, University of Gloucestershire, United Kingdom.

Shaver, J. M., \& Flyer, F. (2000). Agglomeration Economies, Firm Heterogeneity, and Foreign Direct Investment in the United States. Strategic Management Journal, 21(12), 1175-1193.

Stoilova, D. (2017). Tax structure and economic growth: Evidence from the European Union. Contaduría y Administración, 62(3), 1041-1057.

Szarowska, I. (2010). Changes in Taxation and their Impact on Economic Growth in the European Union. Munich Personal RePEc Archive (MPRA) Paper No. 32354

Tosun, M. S., \& Abizadeh, S. (2005). Economic Growth and Tax Components: An Analysis of Tax Changes in OECD. Applied Economics, 37(19), 2251-2263.

Udabah, S. (2002). An Introduction to Nigerian Public Finance. Enugu: Linco Press Nigeria Limited.

Zellner, A., \& Ngoie, J. K. (2015). Evaluation of the Effects of Reduced Personal and Corporate Tax Rates on the Growth Rates of the U.S. Economy. Econometric Reviews, 34(1-2), 56-81. 
Agunbiade, Olabode, Idebi, Alesanmi Abraham

TAX REVENUE AND ECONOMIC GROWTH NEXUS:

EMPIRICAL EVIDENCE FROM THE NIGERIAN ECONOMY

Creative Commons licensing terms

Authors will retain copyright to their published articles agreeing that a Creative Commons Attribution 4.0 International License (CC BY 4.0) terms will be applied to their work. Under the terms of this license, no permission is required from the author(s) or publisher for members of the community to copy, distribute, transmit or adapt the article content, providing a proper, prominent and unambiguous attribution to the authors in a manner that makes clear that the materials are being reused under permission of a Creative Commons License. Views, opinions and conclusions expressed in this research article are views, opinions and conclusions of the author(s).Open Access Publishing Group and European Journal of Economic and Financial Research shall not be responsible or answerable for any loss, damage or liability caused in relation to/arising out of conflict of interests, copyright violations and inappropriate or inaccurate use of any kind content related or integrated on the research work. All the published works are meeting the Open Access Publishing requirements and can be freely accessed, shared, modified, distributed and used in educational, commercial and non-commercial purposes under a Creative Commons Attribution 4.0 International License (CC BY 4.0). 